\title{
PENGARUH BAURAN PEMASARAN TERHADAP KEPUASAN NASABAH DI MAKASSAR (STUDI KASUS PADA NASABAH ASURANSI JASA RAHARJA PUTERA)
}

\author{
E-mail lutvitjia5@gmail.com
}

\begin{abstract}
ABSTRAK
Penelitian ini bertujuan untuk mengkaji dan menganalisis pengaruh bauran pemasaran berupa produk, harga, promosi, lokasi, karyawan, sarana fisik dan proses terhadap peningkatan kepuasan nasabah. Penelitian ini bersifat survey dengan penelitian kuantitatif. Populasi dan sampel penelitian adalah 100 orang responden. Teknik pengumpulan data menggunakan observasi, wawancara, kuesioner, dan teknik dokumentasi. Analisis data yang digunakan adalah Regresi Linier Berganda. Hasil penelitian menunjukkan bahwa bauran pemasaran yang terdiri dari produk, harga, promosi, lokasi, karyawan, bukti fisik dan proses berpengaruh secara simultan positif dan signifikan terhadap kepuasan nasabah, yang ditunjukkan dari hasil perolehan nilai koefisien korelasi (R), koefisien determinan (R2), dan uji-F yang menunjukkan probabilitas $\mathrm{p}<0.05$. Bauran proses yang dominan berpengaruh terhadap kepuasan nasabah, berdasarkan hasil perolehan nilai koefisien regresi (B) yang menunjukkan nilai yang positif yang tinggi dan probabilitas $p<0.05$. Proses merupakan aktivitas yang diterapkan untuk memberikan layanan kepada nasabah mulai dari proses pengambilan nomor antrian, pelayanan pembukaan rekening, akses data sampai sistem online yang dapat memberikan pengaruh terhadap kepuasan nasabah.
\end{abstract}

\section{Kata kunci: $\quad$ Bauran Pemasaran Jasa dan Kepuasan Nasabah}

These research aim to studied and analysis of marketing mix toward increasing of satisfaction by customer. The research survey with quantitative, population and sample as amount 100 respondent. Gathering of data used of observation, interview, questioner and documentation. Data analysis with multiple regression. The result of research showed that the service marketing mix have positive and significant toward satisfaction based on coefficient correlation, coefficient determinant and F-test with probability $p<0.05$. Process have dominant affected toward satisfaction by customer based on coefficient regression value. Process represent the activity which give to customer which affect toward satisfaction bycustomer.

Keywords: $\quad$ Service marketing mix, satisfaction of customer 


\section{PENDAHULUAN}

Pada saat ini, suatu perusahaan baik itu berskala besar maupun berskala kecil memerlukan dan memiliki suatu strategi untuk dapat bersaing dengan kompetitornya. Suatu perusahaan yang baik tentunya harus mempunyai manajemen yang baik pula. Pembahasan tentang manajemen tentu saja tidak lepas dari berbagai faktor sumber daya manusia yang baik dan tentunya dapat menghasilkan suatu kinerja yang berkesinambungan dan dapat saling mendukung untuk menunjang kelangsungan hidup usaha perusahaan.

Kegiatan pemasaran merupakan bagian yang paling penting bagi perusahaan. PT. Asuransi Jasa Raharja Putera sebagai salah satu perusahaan yang bergerak di bidang jasa keuangan yang memberikan pelayanan keuangan kepada masyarakat umum yang berupa perlindungan kepada jiwa untuk keluarga sebagai inti dari semua produk. PT. Jasa Raharja Putera (Persero) disingkat Jasa Raharja Putera adalah sebuah BUMN yang bergerak di bidang asuransi sosial. Strategi yang digunakan adalah dengan mengkombinasikan bauran pemasaran $4 \mathrm{P}$ dan $3 \mathrm{P}$ yaitu bauran pemasaran jasa terdiri atas produk, harga, promosi, tempat, karyawan, bukti fisik dan proses.

Pihak perusahaan berupaya memperbaiki produk dengan menambah jenis asuransi yang ditawarkan kepada masyarakat, misalnya asuransi pendidikan dan asuransi hari tua. Dari aspek harga, tidak mengalami perubahan, namun kurang gencar melakukan promosi, jarang melakukan demonstrasi produk sesuai bukti fisik, karyawan divisi pemasaran masih kurang dan proses pemasangan yang lambat. 
Fenomena bauran pemasaran yang kurang diterapkan oleh pihak dilihat dari sisi penerapan bauran pemasaran produk (product), pihak perusahaan kurang menawarkan produk dengan berbagai jenis, ketersediaan produk asuransi yang masih terbatas dan masih rendahnya jaminan atas asuransi yang ditawarkan.

Kenyataan bauran pemasaran dilihat dari sisi harga (price), terdapat perbedaan harga dengan pesaing lainnya. Harga dalam kaitannya dengan asuransi yang ditawarkan ditentukan oleh imbalan berupa keuntungan, potongan biaya asuransi yang diberikan dan pemberian keuntungan atas setiap produk yang ditawarkan jarang dilakukan perusahaan untuk menambah nasabah.

Menerapkan konsep bauran pemasaran tidak terlepas dari kegiatan promosi (promotion) untuk memperkenalkan dan memberitahu kepada pelanggan tentang produk yang ditawarkan. Promosi berperan penting untuk diperkenalkan kepada pelanggan melalui kegiatan dagang, penjualan dan bisnis.

Dilihat dari bauran pemasaran produk dari sisi tempat (place), secara langsung atau tidak langsung menentukan aktivitas pemasaran. Pelaku pemasaran dalam menjual atau menawarkan produknya banyak dipengaruhi oleh keberadaan tempat sebagai saluran (distribusi), lokasi strategis dan akses tempat yang mudah ditemukan.

Bagi pengembang pemasaran produk dan jasa, hal yang tidak kalah pentingnya memainkan peranan dilihat dari sisi karyawan (people). Karyawan merupakan pelaku pemasaran yang dituntut untuk memiliki penampilan menarik, mampu bekerja dalam tim kerja, selalu bekerjasama dan berkomunikasi efektif untuk melakukan kegiatan pemasaran.

Aktivitas pemasaran juga tidak terlepas dari sisi bukti fisik (physical evidence). Perusahaan dalam mengembangkan aktivitas pemasaran jasa berusaha untuk memenangkan persaingan dengan menyediakan, melengkapi dan memperbaharui segala bukti fisik yang dimiliki baik berupa penggunaan alat modern, perlengkapan yang canggih, gedung yang besar dan armada yang banyak. 
Aktivitas pemasaran produk dan jasa juga ditentukan dari sisi proses (process). Fenomena yang terlihat saat ini pada perusahaan Prima Vision memperlihatkan bahwa kegiatan proses pelayanan dan operasional yang dilakukan cenderung belum sesuai dengan ketentuan prasyarat layanan, standarnisasi layanan, prosedur layanan yang dilakukan dan sistem kerja yang diterapkan. Proses pelayanan yang dilakukan belum berorientasi pada pelayanan yang cepat, mudah dan lancar.

Konsep bauran pemasaran yang diterapkan oleh PT. Jasa Raharja Putera (Persero) bertujuan untuk mengembangkan kondisi lingkungan perusahaan asuransi itu sendiri dalam menghadapi persaingan yang ketat, kuatnya regulasi yang diterapkan dalam praktik yang cenderung menjadi suatu dilema di dalam pengambilan keputusan menggunakan jasa asuransi yang berkaitan dengan aset- aset dana masyarakat. Demikian pula kuatnya motivasi dari masyarakat di dalam melihat dan memahami tentang regulasi bidang asuransi yang menimbulkan adanya tingkat kehati-hatian (prudential) yang cenderung menjadi suatu mossy tidak percaya, yang dikhawatirkan dapat menimbulkan adanya ketidakpercayaan (trust), sehingga tingkat likuiditas akan menurun dan profitabilitas perusahaan sulit meningkat, yang pada akhirnya menyebabkan masyarakat tidak percaya lagi.

Fenomena yang ada saat ini adalah bagaimana menerapkan suatu sistem pelayanan pemasaran yang terpadu yaitu memasarkan produk dan memberikan jasa asuransi yang berkualitas, secara langsung atau tidak langsung akan memberikan suatu citra positif bagi nasabah yaitu terpenuhinya harapan yang diinginkan dari kenyataan yang dibayangkan, sehingga apresiasi mengenai kepuasan atas pelayanan yang diberikan oleh pihak bank menjadi unsur penting dalam menggugah dan menanamkan loyalitas nasabah untuk bermitra dengan PT. Jasa Raharja Putera (Persero). 
Memahami pemasaran produk dan jasa yang dikemukakan di atas berdasarkan fenomena, maka wajar bila dikemukakan sebuah pandangan teori konsep 7P yang dikemukakan oleh Payne (2000:105) menyatakan bahwa untuk memenangkan persaingan dalam pemasaran produk dan jasa, perlu mempertimbangkan konsep 7P (product, price, promotion, place, physical evidence, people, process) dalam rangka memenuhi kepuasan nasabah.

Perusahaan PT. Jasa Raharja Putera saat ini kurang mempertimbangkan kepuasan pelanggan atas pelayanan asuransi. Ketidakpuasan pelanggan dikarenakan tidak terpenuhinya kebutuhan asuransi yang sesuai kenyataan, keinginan pembayaran iuran bulan yang terjangkau tidak dipenuhi, kesesuaian harapan dan tujuan atas jenis asuransi yang ditawrkan. Parker dan Mathews (2001:38) menyatakan bahwa kepuasan merupakan unsur penting dari pemasaran jasa. Kepuasan merupakan pengungkapan perasaan terhadap pemenuhan kebutuhan, keinginan, harapan dan tujuan.

Berdasarkan uraian latar belakang yang dikemukakan di atas, maka peneliti mempertimbangkan untuk mengkaji dan meneliti tentang konsep bauran pemasaran yang memadukan pemasaran produk dan jasa terhadap peningkatan kepuasan nasabah dengan memilih judul: Pengaruh Bauran Pemasaran terhadap Kepuasan Nasabah di Makassar (Studi Kasus pada Nasabah Asuransi Jasa Raharja Putera). 


\section{BAHAN DAN METODE}

Penelitian ini dirancang untuk menjawab permasalahan yang telah dirumuskan dan tujuan yang hendak dicapai serta menguji hipotesis. Rancangan penelitian menurut Kerlinger (2000) merupakan suatu struktur penyelidikan yang disusun sedemikian rupa, sehingga peneliti dapat memperoleh jawaban untuk pertanyaan-pertanyaan penelitian, dibedakan sebagai berikut:

1. Penelitian ini merupakan penelitian exploratory yaitu berusaha untuk mencari hubungan-hubungan yang relatif baru, dan explanatory yaitu penelitian yang dilakukan dengan cara menjelaskan gejala yang ditimbulkan oleh suatu obyek penelitian.

2. Ditinjau dari aspek datanya adalah penelitian ex post facto, yang berarti setelah kejadian yaitu penelitian yang bersifat pencarian empirik yang sistematik, di mana peneliti tidak dapat mengontrol variabel bebasnya karena peristiwa telah terjadi atau sifatnya tidak dapat dimanipulasi.

3. Ditinjau dari tujuannya adalah studi kausal yang berusaha menjelaskan analisis pengaruh bauran pemasaran jasa asuransi pada PT. Jasa Raharja Putera.

\section{Tempat dan Waktu Penelitian}

Tempat penelitian dilaksanakan di Kota Makassar, dengan obyek penelitian nasabah PT. Jasa Raharja Putera. Lokasi penelitian ini dipilih dengan pertimbangan bahwa peneliti mudah memperoleh data penelitian baik yang bersifat data primer maupun data sekunder. Waktu penelitian dilaksanakan selama tiga bulan mulai Oktober sampai Desember 2013. 


\section{Populasi dan Sampel}

\section{Populasi}

Populasi merupakan seluruh obyek yang dijadikan pengamatan untuk dilakukan penarikan sampel. Populasi penelitian ini adalah nasabah asuransi pada PT. Jasa Raharja Putera yang telah menjadi nasabah mulai tahun 2011 sampai sekarang yang berjumlah 22.571 orang.

\section{Sampel}

Sampel adalah kumpulan sampling unit yang dipilih dari suatu kerangka sampling. Emory dan Cooper (1991) mengemukakan bahwa sampel adalah bagian dari populasi yang dipilih secara cermat untuk mewakili populasi. Berkaitan dengan penelitian yang bekerja dengan sampel, dikemukakan oleh Singarimbun (1995) bahwa penelitian survei adalah penelitian yang mengambil sampel dari suatu populasi dan menggunakan kuesioner sebagai alat pengumpulan data yang pokok. Dengan menggunakan rumus Slovin diperoleh jumlah responden sebesar 100 orang, sebagaiberikut.

$$
\mathrm{n}=\frac{N}{1+N e^{2}}
$$

Keterangan:

$$
\begin{array}{ll}
\mathrm{n} & =\text { Jumlah Sampel } \\
\mathrm{N} & =\text { Besar Populasi } \\
\mathrm{e} & =\text { Tingkat Kepercayaan }(10 \%=0.10)
\end{array}
$$

Jadi besar sampel:

$$
\begin{aligned}
& n=-\frac{22.571}{1+(22.571)(0.10)^{2}} \\
& n=-\frac{22.571}{1+(22.571)(0.01)}
\end{aligned}
$$




$$
\begin{aligned}
& n=\frac{22.571}{1+225.71} \\
& n=\frac{22.571}{226.71} \\
& n=99.5 \\
& n=100 \text { (dibulatkan) }
\end{aligned}
$$

Jadi besar sampel penelitian adalah 100 orang.

\section{Jenis dan Sumber Data}

Jenis data adalah kualitatif dan kuantitatif yang bersumber dari:

\section{Data Primer}

Data primer adalah data yang diperoleh secara langsung di lapangan yang bersumber hasil pengamatan langsung analisis pengaruh bauran pemasaran jasa asuransi pada PT. Jasa Raharja Putera.

\section{Data Sekunder}

Data sekunder yaitu data pendukung bagi data primer yang diperoleh dari bahan-bahan literatur seperti dokumen-dokumen serta laporan-laporan dan kepustakaan lainnya yang berkaitan dengan analisis pengaruh bauran pemasaran jasa asuransi pada PT. Jasa Raharja Putera.

\section{Teknik Pengumpulan Data}

Teknik pengumpulan data yang digunakan adalah wawancara, observasi, kuesioner dan telaah dokumen:

1. Observasi, yaitu teknik pengumpulan data di mana peneliti terlibat langsung untuk mengamati analisis pengaruh bauran pemasaran jasa asuransi pada PT. Jasa Raharja Putera.

2. Wawancara yaitu mengumpulkan data melalui wawancara secara langsung. 
3. Penyebaran kuesioner digunakan untuk mendapatkan data kuantitatif terdiri dari variabel bebas dan variabel terikat. Teknik pengukuran, menggunakan Skala Likert. Teknik ini dilakukan dengan mengajukan pertanyaan kepada responden untuk dijawab sesuai dengan tingkat penerimaan responden. Sifat pertanyaan tertutup, artinya jawaban sudah ditentukan oleh peneliti, responden tinggal memilih jawaban yang tersedia. Jawaban terdiri dari lima kategori yaitu 5,4,3,2,1, di mana masing-masing jawaban akan ditabulasikan, sehingga diperoleh nilai rata-ratanya

4. Studi dokumentasi yaitu teknik pengumpulan data dengan cara mempelajari buku-buku maupun jurnal yang berkaitan dengan topik pembahasan.

\section{Variabel Penelitian dan Definisi Operasional}

Definisi operasional digunakan agar tidak menimbulkan penafsiran ganda yaitu dengan memberikan batasan terhadap variabel-variabel yang digunakan dalam penelitian ini yaitu:

1. Produk adalah bauran pemasaran berupa asuransi yang nyata ditawarkan langsung atau tidak langsung ke nasabah. Indikator produk mengacu pada konsep product menurut Kotler (2010:63) terdiri dari:

a. Jenis produk adalah ragam asuransi yang ditawarkan kepada nasabah.

b. Ketersediaan produk adalah keberadaan jenis asuransi yang tersedia dan dapat dimiliki oleh nasabah.

c. Kualitas produk adalah jaminan mutu dari asuransi yang ditawarkan kepada nasabah.

2. Harga adalah penetapan balas jasa sesuai dengan nilai produk. Indikator harga mengacu pada konsep price menurut Kotler (2010:68) terdiridari:

a. Imbalan adalah keuntungan yang diperoleh dari mengikuti asuransi.

b. Diskon adalah potongan biaya atas asuransi yang diberikan pada nasabah. 
c. Bonus adalah pemberian keuntungan kepada nasabah atas produk asuransi yang ditawarkan.

3. Promosi adalah memperkenalkan dan memberitahu produk asuransi yang ditawarkan. Indikator promosi mengacu pada konsep promotion menurut Kotler (2010:78):

a. Promosi nasabah adalah memperkenalkan produk asuransi langsung kepada nasabah.

b. Promosi dagang adalah kegiatan pemberitahuan atau iklan produk asuransi ke nasabah.

c. Promosi penjualan adalah kegiatan pengenalan produk asuransi dengan langsung melakukan penjualan ke nasabah.

d. Promosi bisnis adalah kegiatan pengenalan produk asuransi melalui mitra bisnis ke nasabah.

4. Tempat adalah lokasi pemasaran produk yang dipasarkan ke nasabah. Indikator tempat mengacu pada konsep place menurut Kotler (2010:85):

a. Saluran adalah wadah/tempat menyalurkan produk asuransi dari satu tempat ke tempat lain.

b. Lokasi strategis adalah tempat produk asuransi ditawarkan.

c. Akses adalah ketersediaan berbagai informasi produk asuransi yang mudah diperoleh.

5. Karyawan adalah orang yang menawarkan jasa kepada nasabah. Indikator karyawan mengacu pada konsep people menurut Keller (2011:18):

a. Penampilan adalah tampilan menarik karyawan dalam menawarkan jasa asuransi kepada nasabah.

b. Tim kerja adalah kemampuan mengembangkan jasa dalam satuan tim kerja yang solid kepada nasabah.

c. Kerjasama adalah wujud kebersaman dalam memberikan pelayanan kepada nasabah. 
d. Komunikasi adalah interaksi lewat dialog intensif antara karyawan dengan nasabah dalam pemberian jasa.

6. Bukti fisik adalah wujud barang dan jasa yang dapat dinikmati langsung oleh nasabah. Indikator bukti fisik mengacu pada konsep physical evidence menurut Keller (2011:25) yaitu:

a. Alat adalah bukti fisik yang digunakan dalam memberikan pelayanan asuransi yang mudah kepada nasabah.

b. Perlengkapan adalah bukti fisik yang digunakan untuk memperlancar kegiatan pelayanan asuransi kepada nasabah.

c. Gedung/kantor adalah wadah bukti fisik untuk memberikan pelayanan kepada nasabahnya.

d. Armada adalah satuan bukti fisik berupa orang yang siap siaga memberikan pelayanan kepada nasabah.

7. Proses adalah serangkaian kegiatan jasa yang diberikan kepada nasabah. Indikator proses mengacu pada konsep process menurut Keller (2011:37) yaitu:

a. Prasyarat adalah ketentuan yang dimiliki untuk melakukan proses pelayanan asuransi nasabah.

b. Standarnisasi adalah standar pelayanan asuransi yang harus terproses dengan baik kepada nasabah.

c. Prosedur adalah mekanisme proses pelayanan asuransi yang harus dilalui oleh nasabah.

d. Sistem kerja adalah serangkaian proses aktivitas pelayanan dalam melayani nasabah.

8. Kepuasan adalah ungkapan perasaan atas penerimaan jasa asuransi yang diterima nasabah. Indikator mengacu kepada teori satisfied menurut Parker dan Mathews (2001) terdiri atas:

a. Kebutuhan adalah terpenuhinya perasaan tentang kecukupan terhadap jasa asuransi. 
b. Keinginan adalah terpenuhinya perasaan tentang dambaan jasa asuransi yang sesuai.

c. Harapan adalah pengungkapan perasaan sesuai dengan yang dicita-citakan.

d. Tujuan adalah pengungkapan perasaan tentang jasa terhadap pencapan sasaran.

Lebih jelasnya disajikan pada Tabel 3.1 di bawah ini:

Tabel 3.1

Definisi Operasional Variabel Penelitian

\begin{tabular}{|c|c|c|c|c|}
\hline No & Variabel & Konsep & Indikator & Pengukuran \\
\hline 1 & Produk $\left(\mathrm{X}_{1}\right)$ & $\begin{array}{l}\text { Bauran pemasaran } \\
\text { berupa barang yang } \\
\text { nyata dapat dibeli } \\
\text { langsung atau tidak } \\
\text { langsung dari produsen } \\
\text { ke konsumen }\end{array}$ & $\begin{array}{ll}\text { - } & \text { Jenis produk } \\
\text { - } & \text { Ketersediaan } \\
& \text { produk } \\
\text { - } & \text { Kualitas produk }\end{array}$ & Skala Likert \\
\hline 2 & Harga $\left(X_{2}\right)$ & $\begin{array}{l}\text { Penetapan balas jasa } \\
\text { sesuai dengan nilai } \\
\text { produk }\end{array}$ & $\begin{array}{l}\text { - Imbalan } \\
\text { - Diskon } \\
\text { - Bonus }\end{array}$ & $5,4,3,2,1$ \\
\hline 3 & Promosi $\left(\mathrm{X}_{3}\right)$ & $\begin{array}{l}\text { Memperkenalkan dan } \\
\text { memberitahu produk } \\
\text { yang ditawarkan }\end{array}$ & $\begin{array}{l}\text { - Promosi } \\
\text { pelanggan } \\
\text { - Promosi dagang } \\
\text { - Promosi sales } \\
\text { - Promosi bisnis }\end{array}$ & Skala Likert \\
\hline 4 & Tempat $\left(\mathrm{X}_{4}\right)$ & $\begin{array}{l}\text { Lokasi pemasaran produk } \\
\text { yang dipasarkan ke } \\
\text { pelanggan }\end{array}$ & $\begin{array}{l}\text { - Saluran } \\
\text { - Lokasi } \\
\text { - Akses } \\
\end{array}$ & $5,4,3,2,1$ \\
\hline 5 & Karyawan $\left(X_{5}\right)$ & $\begin{array}{l}\text { Orang yang menawarkan } \\
\text { jasa kepada pelanggan }\end{array}$ & $\begin{array}{l}\text { - Penampilan } \\
\text { - Tim kerja } \\
\text { - Kerjasama } \\
\text { - Komunikasi }\end{array}$ & Skala Likert \\
\hline 6 & Bukti fisik $\left(\mathrm{X}_{6}\right)$ & $\begin{array}{l}\text { Wujud barang dan jasa } \\
\text { yang dapat dinikmati } \\
\text { langsung oleh pelanggan }\end{array}$ & $\begin{array}{l}\text { - Alat } \\
\text { - Perlengkapan } \\
\text { - Gedung/kantor } \\
\text { - Armada }\end{array}$ & $5,4,3,2,1$ \\
\hline 7 & Proses $\left(\mathrm{X}_{7}\right)$ & $\begin{array}{l}\text { Serangkaian kegiatan } \\
\text { jasa yang diberikan } \\
\text { kepada pelanggan }\end{array}$ & $\begin{array}{l}\text { - Prasyarat } \\
\text { - Standarnisasi } \\
\text { - Prosedur } \\
\text { - Sistim kerja }\end{array}$ & Skala Likert \\
\hline 8 & Kepuasan (Y) & $\begin{array}{l}\text { Ungkapan perasaan atas } \\
\text { penerimaan jasa yang } \\
\text { diterima pelanggan }\end{array}$ & $\begin{array}{l}\text { - Kebutuhan } \\
\text { - Keinginan } \\
\text { - Harapan } \\
\text { - Tujuan }\end{array}$ & $\begin{array}{l}\text { Skala Likert } \\
5,4,3,2,1\end{array}$ \\
\hline
\end{tabular}




\section{Metode Analisis}

Untuk menguji hipotesis yang telah diajukan dalam penelitian ini, maka digunakan metode analisis:

1. Analisis kualitatif deskriptif, yaitu dengan menganalisis data kualitatif yang telah diperoleh melalui wawancara, kuesioner dan dokumentasi.

2. Analisis regresi linier berganda yaitu dengan mengambil jawaban dari lembar kuesioner yang telah dijawab oleh responden. Analisis dilakukan untuk mengetahui analisis pengaruh bauran pemasaran jasa asuransi pada PT. Jasa Raharja Putera.

Rumus regresi linier berganda merupakan sebagai berikut: (Santoso, 2004:29)

$$
Y=\beta_{0}+\beta_{1} X_{1}+\beta_{2} X_{2}+\beta_{3} X_{3}+\beta_{4} X_{4}+\beta_{5} X_{5}+\beta_{6} X_{6}+\beta_{7} X_{7}+\varepsilon_{i}
$$




$$
\begin{gathered}
\mathrm{R}_{\mathrm{TSS}}^{\underset{\mathrm{JKST}}{\mathrm{EtauS}}} \mathrm{R}^{2}=\underset{\mathrm{JKR}}{\mathrm{JKT}} \\
\mathrm{JKR}=\text { jumlah kuadrat regresi } \\
\beta 1 \Sigma 1 \mathrm{Y}+\beta 2 \Sigma 2 \mathrm{Y}+\ldots \ldots \ldots+ \\
\mathrm{JKT}=\text { jumlah kuadrat total } \\
\left(\Sigma \mathrm{Y}^{2}\right) \\
\Sigma \mathrm{Y} 2=\Sigma \mathrm{Y} 2-\quad \mathrm{n}
\end{gathered}
$$

Sifat penting $\mathrm{R}^{2}$ merupakan bahwa nilai tersebut di atas merupakan fungsi yang tidak pernah menurun (non decreasing function) dari banyaknya variabel- variabel yang dijelaskan dalam model, sering dengan meningkatnya jumlah variabel yang menjelaskan, $\mathrm{R}^{2}$ hampir-hampir selalu meningkat dan tak pernah menurun.

Total SS $=$ Sum of Square

Selanjutnya untuk melihat dominasi masing-masing variabel, dapat dilihat dengan membandingkan koefisien determinasi parsial $\left(r^{2}\right)$. Semakin besar $r^{2}$ suatu variabel bebas menunjukkan dominan variabel bebas tersebut terhadap variabel tergantungnya, dan sebaliknya koefisien determinasi parsial $\left(r^{2}\right)$ dapat dihitung melalui koefisien regresi dengan rumus : (Arif Tiro, 2004:32)

$$
\begin{aligned}
& \mathrm{r} \beta \beta^{2}= \\
& \mathrm{t} \beta^{2}+\mathrm{n}-\mathrm{k}-1
\end{aligned}
$$

Dilanjutkan dengan pengujian varians atau sering disebut sebagai Uji-F. Apabila hasil perhitungan menunjukkan bahwa Fo (observasi) > Ft maka Ho ditolak dan Ha diterima. Dengan demikian, jika kondisi dapat tercapai maka dapat dikatakan bahwa variasi model regresi tersebut dapat menerangkan variasi variabel tergantungnya. Fo dapat dihitung dengan menggunakan rumus dari Kerlinger, sebagai berikut : (Arif Tiro, 2004:33) 
Untuk menjamin kesejahteraan masyarakat, terutama untuk meringankan beban hidup masyarakat akibat korban kecelakaan lalu lintas, maka pemerintah mendirikan perusahaan asuransi kecelakaan lalu lintas kecelakaan lalu lintas. Sebagai wujud dari realisasi tersebut adalah pendirian Perusahaan Negara Asuransi Kerugian Jasa Raharja Putera (PN AKJR) pada tanggal 1 Januari 1965 berdasarkan peraturan Pemerintah No. 8 Tahun 1965. Adapun tugas Jasa Raharja Putera adalah melaksanakan UU No. 33 tahun 1964 untuk menyantuni korban kecelakaan penumpang darat, laut dan udara dan UU No. 33 Tahun 1964 untuk menyantuni korban kecelakaan penumpang darat, laut dan udara dan UU No. 34 Tahun 1964 untuk menyantuni korban kecelakaan lalu lintas jalan akibat tertabrak kendaraan bermotor, tabrakan dua kendaraan atau lebih dan tertabrak kereta api.

Dikarenakan tugas yang diemban makin berat seiring dengan kondisi perekonomian terkini, maka pemerintah menaikkan statusnya dari Perusahaan Negara menjadi Perusahaan Umum Jasa Raharja Putera (Perum Jasa Raharja Putera) pada tahun 1970. Hingga akhirnya pada tahun 1980, berdasarkan PP No.

39 Tahun 1980, status Jasa Raharja Putera diubah lagi menjadi Perusahaan Perseroan (Persero) dengan nama PT. (Persero) Asuransi Kerugian Jasa Raharja Putera. Pada tahun 1978, Jasa Raharja Putera mendapat tugas untuk menerbitkan surat jaminan dalam bentuk Surety Bond. Hanya saja penugasan ini berakhir pada tahun 1994, sejalan dengan diterbitkan UU No. 2 Tahun 1992 tentang Usaha Perasuransian, yang antara lain mengharuskan bahwa Perusahaan Asuransi telah menyelenggarakan program asuransi sosial di larang menjalankan asuransi lain 
selain program asuransi sosial. Atas amanat undang-undang, maka terhitung mulai tanggal 1 Januari 1994, Jasa Raharja Putera melepaskan usaha non wajib dan surety bond untuk kembali menjalankan program asuransi sosial.

Jasa Raharja Putera yang melayani masyarakat sampai sekarang merupakan hasil peleburan Perusahaan Asuransi Kerugian Negara (PAKN) "Ika Karya" dan, PAKN "Ika Karya" sendiri merupakan hasil penggabungan empat perusahaan asuransi nasional yang sebelumnya milik perusahaan Belanda. Keempat perusahaan asuransi ini merupakan hasil penggabungan delapan perusahaan asuransi Belanda yang dipecah menjadi dua tahap hingga akhirnya sampai menjadi PT. Jasa Raharja Putera (Persero) seperti sekarang ini. PT. Jasa Raharja Putera (Persero) bergerak di bidang usaha penyelenggara program asuransi sosial yang menjalankan amanat undang-undang yaitu:

1. UU No. 33 Tahun 1964 jo PP No. 17 Tahun 1965 tentang Dana Pertanggungan Wajib Kecelakaan Penumpang.

2. UU No. 34 Tahun 1964 jo PP No. 18 Tahun 1965 tentagn Dana Kecelakaan Lalu Lintas Jalan.

3. Menerima pertanggungan tidak langsung untuk ditahan sendiri oleh perseroan. Visi yang diemban PT. Jasa Raharja Putera (Persero) adalah "Menjadi Perusahaan Terkemuka Di Bidang Asuransi dengan Mengutamakan Penyelenggaraan Program Asuransi Sosial dan Asuransi Wajib sejalan dengan Kebutuhan Masyarakat." Sejalan dengan visi di atas, maka misi PT. Jasa Raharja Putera (Persero) adalah Catur Bakti Ekakarsa Jasa Raharja Putera:

1. Bakti kepada Masyarakat, dengan mengutamakan perlindungan dasar dan pelayanan prima sejalan dengan kebutuhan masyarakat.

2. Bakti kepada Negara, dengan mewujudkan kinerja terbaik sebagai penyelenggara Program Asuransi Sosial dan Asuransi Wajib, serta Badan Usaha Milik Negara. 
3. Bakti kepada Perusahaan, dengan mewujudkan keseimbangan kepentingan agar produktivitas dapat tercapai secara optimal demi kesinambungan perusahaan.

4. Bakti kepada Lingkungan, dengan memberdayakan potensi sumber daya bagi keseimbangan dan kelestarian lingkungan.

Struktur organisasi perusahaan asuransi PT. Jasa Raharja Putera (Persero) terdiri atas Dewan Komisaris yang membawahi Direktur Utama. Direktur Utama membawahi Direktur Operasi, Direktur Umum dan Direktur Keuangan. Direktur Utama juga membawahi langsung bagian divisi litbang, SPI dan divisi SIP. Untuk Direktor Operasi membawahi divisi asuransi dan pelayanan. Direktur Umum membawahi divisi SDM, divisi umum dan sekretariat perusahaan. Sedangkan untuk Direktur Keuangan membawahi divisi keuangan dan divisi akuntansi. Lebih jelasnya ditunjukkan bagan struktur organisasi PT. Jasa Raharja Putera (Persero). 


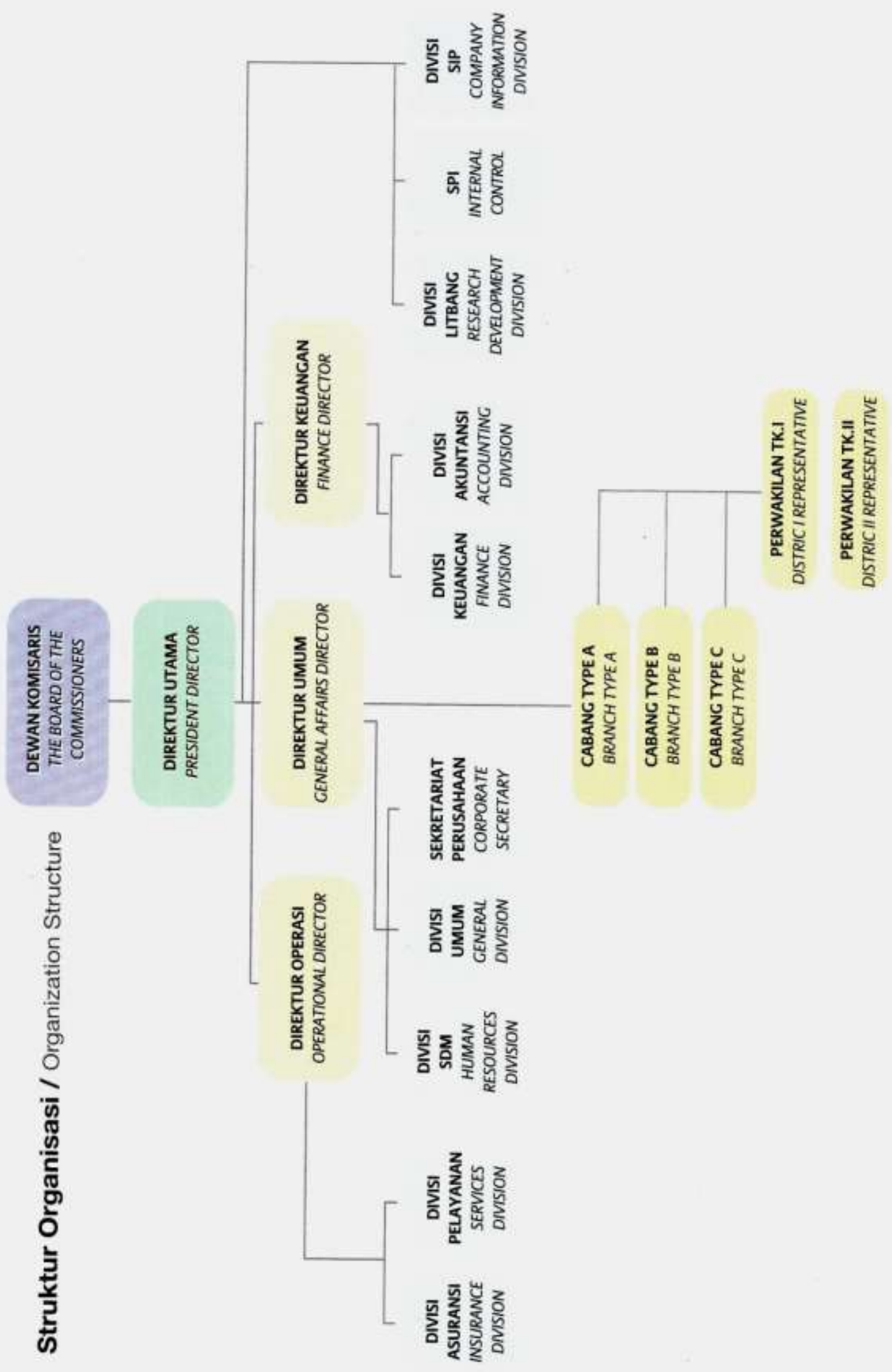




\section{Hasil Penelitian}

\section{Karakteristik Responden}

Karakteristik responden adalah penjelasan tentang keberadaan responden dalam hal ini nasabah pada PT. Jasa Raharja Putera (Persero) Tbk. Makassar, yang diperlukan sebagai informasi untuk mengetahui identitas sebagai responden dalam penelitian ini. Responden sebagai obyek penelitian yang memberikan interpretasi terhadap karakteristik responden untuk menganalisis faktor bauran pemasaran yang berpengaruh terhadap kepuasan nasabah.

Responden dalam penelitian ini sebanyak 100 orang responden yang representatif untuk dikemukakan sebagai kelayakan responden dalam memberikan informasi mengenai identitas diri mulai dari jenis kelamin, umur dan pendidikan. Lebih jelasnya akan diuraikan sebagai berikut:

\section{Umur}

Umur ada usia yang dimiliki responden guna memudahkan untuk mengetahui sejauhmana tingkat kepuasan nasabah atas penerapan bauran pemasaran. Lebih jelasnya umur responden ditunjukkan pada Tabel 4.1 sebagai berikut:

Tabel 4.1

Frekuensi dan Persentase Umur

\begin{tabular}{|c|c|c|}
\hline Umur & Frekuensi (F) & $\begin{array}{l}\text { Persentase } \\
(\%)\end{array}$ \\
\hline $26-30$ & 5 & 5.0 \\
$31-35$ & 17 & 17.0 \\
$36-40$ & 40 & 40.0 \\
$>40$ & 38 & 38.0 \\
\hline Total & 100 & 100.0 \\
\hline
\end{tabular}

Sumber: Data setelah diolah, 2014

Tabel $4.1 \mathrm{di}$ atas terlihat sebanyak 38 orang atau $38.0 \%$ berusia antara $>40$ tahun, 40 orang atau $40.0 \%$ berusia antara $36-40$ tahun, 
17 orang atau $17.0 \%$ berusia antara 31 - 35 tahun dan sebanyak 5 orang atau $5.0 \%$ berusia $26-30$ tahun. Ini menunjukkan bahwa usia responden kebanyakan telah berusia dewasa dan matang menilai suatu penerapan bauran pemasaran untuk dapat memberikan kepuasan atas layanan produk dan jasa pada PT. Jasa Raharja Putera (Persero) Tbk. Makassar.

\section{Jenis Kelamin}

Jenis kelamin terdiri atas laki-laki dan perempuan guna mengetahui proporsi dari responden laki-laki dan perempuan yang menjadi nasabah pada PT. Jasa Raharja Putera (Persero) Tbk. Makassar . Lebih jelasnya dapat dilihat pada Tabel 4.2 sebagai berikut:

Tabel 4.2

Frekuensi dan Persentase Jenis Kelamin

\begin{tabular}{|c|c|c|}
\hline Jenis Kelamin & Frekuensi (F) & $\begin{array}{l}\text { Persentase } \\
(\%)\end{array}$ \\
\hline Laki-laki & 89 & 89.0 \\
Perempuan & 11 & 11.0 \\
\hline Total & 100 & 100.0 \\
\hline
\end{tabular}

Sumber: Data setelah diolah, 2014

Tabel 4.2 di atas terlihat sebanyak 89 orang atau $89.0 \%$ adalah laki-laki dan perempuan sebanyak 11 orang atau $11.0 \%$. Terlihat responden nasabah pada PT. Jasa Raharja Putera (Persero) Tbk. Makassar kebanyakan adalah laki-laki.

\section{Pendidikan}

Pendidikan adalah jenjang pendidikan yang ditamati oleh responden sesuai dengan latar belakang pendidikan dan disiplin ilmu yang ditekuni dan diakui oleh pemerintah atas tamatan pendidikan yang dimilikinya. Jelasnya dapat dilihat Tabel 4.3 sebagaiberikut: 
Tabel 4.3

Frekuensi dan Persentase Pendidikan

\begin{tabular}{|c|c|c|}
\hline Pendidikan & Frekuensi (F) & $\begin{array}{l}\text { Persentase } \\
(\%)\end{array}$ \\
\hline S2 & 5 & 5.0 \\
S1 & 70 & 70.0 \\
D3 & 16 & 16.0 \\
SMA & 9 & 9.0 \\
\hline Total & 100 & 100.0 \\
\hline
\end{tabular}

Sumber: Data setelah diolah, 2014

Tabel 4.3 di atas terlihat yang paling banyak adalah responden dengan pendidikan S1 sebanyak 70 orang atau $70.0 \%$ dan berpendidikan S2 ada 5 orang atau $5.0 \%$. Selain itu terlihat responden yang berpendidikan D3 ada 16 orang atau $16.0 \%$ dan SMA sebanyak 9 orang atau 9.0\%. Melihat tingkat pendidikan responden tersebut, sudah cukup layak untuk mengetahui sejauhmana kepuasan nasabah pada PT. Jasa Raharja Putera (Persero) Tbk. Makassar atas penerapan bauran pemasaran.

\section{Perkembangan Asuransi Jasa Raharja Putera}

Perkembangan Asuransi Jasa Raharja Putera merupakan data mengenai keberadaan nasabah perusahaan dan nasabah yang telah melakukan klaim selama menggunakan jasa asuransi. Berikut ditunjukkan data tersebut dalam kurun waktu tiga tahun (2011 - 2013) pada Tabel 4.4 di bawah ini:

Tabel 4.4

Data Perkembangan Jumlah Nasabah Asuransi Jasa Raharja Putera Tahun 2011 2013

\begin{tabular}{|c|c|c|c|c|}
\hline \multirow{2}{*}{ Tahun } & \multicolumn{2}{|l|}{ Nasabah Tetap } & \multicolumn{2}{l|}{$\begin{array}{l}\text { Nasabah yang } \\
\text { Mengklaim }\end{array}$} \\
\cline { 2 - 5 } & $\mathrm{F}$ & $\%$ & $\mathrm{~F}$ & $\%$ \\
\hline 2011 & 598 & 0.0 & 98 & 0.0 \\
2012 & 622 & 21.1 & 116 & 32.1 \\
2013 & 712 & 78.9 & 154 & 67.9 \\
\hline
\end{tabular}

Sumber: PT. Jasa Raharja Putera Makassar 
Tabel di atas menunjukkan bahwa dalam kurun waktu tiga tahun jumlah nasabah mengalami peningkatan. Antara tahun 2011 sampai 2012 terlihat peningkatan sebesar 21.1\% dan antara tahun 2012 sampai 2013 mengalami peningkatan hingga mencapai 78.9\%. Sama dengan peningkatan jumlah nasabah asuransi, demikian pula dalam hal nasabah yang melakukan klaim terlihat juga mengalami peningkatan yaitu sebesar $32.1 \%$ antara tahun 2011 sampai 2012 dan $67.9 \%$ antara tahun 2012 sampai 2013. Untuk itu penting bagi perusahaan dalam menerapkan bauran pemasaran dalam rangka mewujudkan kepuasan nasabah.

\section{Deskripsi Variabel Penelitian}

Deskripsi variabel penelitian adalah penjelasan mengenai analisis pengaruh bauran pemasaran terhadap kepuasan nasabah pada PT. Jasa Raharja Putera (Persero) Tbk. Makassar. Penilaian variabel didasarkan pada tanggapan responden sebagai responden yang memberikan informasi sesuai pertanyaan yang diajukan dalam kuesioner. Lebih jelasnya akan diuraikan sebagai berikut:

\section{Kepuasan Nasabah (Y)}

Kepuasan nasabah adalah apresiasi perasaan nasabah atas penilaian pelayanan yang diberikan oleh pihak jasa asuransi dari penawaran produk dan jasa yang dikehendaki. Kepuasan nasabah ditentukan oleh terpenuhinya harapan atas produk dan jasa serta terpenuhinya keinginan atas produk dan jasa. Berikut tanggapan responden mengenai kepuasan nasabah ditunjukkan pada Tabel 4.4 dibawah ini: 
Tabel 4.4

Frekuensi dan Persentase mengenai Kepuasan Nasabah

\begin{tabular}{|c|c|c|c|}
\hline \multirow{2}{*}{ Kategori } & \multirow{2}{*}{$\begin{array}{l}\text { Skala Interval } \\
\text { Likert }\end{array}$} & \multicolumn{2}{|c|}{ Responden } \\
\hline & & $\begin{array}{l}\text { Frekuensi } \\
\text { (F) }\end{array}$ & $\begin{array}{l}\text { Persentase } \\
(\%)\end{array}$ \\
\hline Sangat Sesuai & $4.01-5.00$ & 40 & 40.0 \\
\hline Sesuai & $3.01-4.00$ & 57 & 57.0 \\
\hline Kurang Sesuai & $2.01-3.00$ & 3 & 3.0 \\
\hline Tidak Sesuai & $1.01-2.00$ & 0 & 0.0 \\
\hline Sangat Tidak Sesuai & $0.00-1.00$ & 0 & 0.0 \\
\hline Total & & 100 & 100.0 \\
\hline
\end{tabular}

Sumber: Data setelah diolah, 2014

Tabel 4.4 terlihat frekuensi dan persentase tanggapan responden mengenai kepuasan nasabah jawaban responden berada pada kategori sesuai yang dinyatakan sebanyak 57 orang atau $57.0 \%$. sebanyak 40 orang atau $40.0 \%$ menyatakan sangat sesuai dan 3 orang atau $3.0 \%$ menyatakan kurang sesuai. Artinya responden nasabah dalam penelitian ini kebanyakan telah puas atas bauran pemasaran produk dan jasa yang diterapkan perusahaan PT. Jasa Raharja Putera (Persero) Tbk. Makassar karena bauran pemasaran yang diterapkan telah sesuai dalam memenuhi harapan dan keinginan nasabah atas produk dan jasa.

\section{Produk (X1)}

Produk adalah suatu bentuk pelayanan yang berwujud atau tidak berwujud yang dirasakan nasabah sebagai sesuatu yang dapat dinilai berupa benda atau jasa. Produk yang ditawarkan tersebut berdasarkan jenis produk, ketersediaan produk dan kualitas dari produk asuransi. Berikut tanggapan responden mengenai bauran pemasaran produk ditunjukkan pada Tabel 4.5 dibawah ini: 
Tabel 4.5

Frekuensi dan Persentase mengenai Produk

\begin{tabular}{|c|c|c|c|}
\hline \multirow[b]{2}{*}{ Kategori } & \multirow{2}{*}{$\begin{array}{l}\text { Skala Interval } \\
\text { Likert }\end{array}$} & \multicolumn{2}{|c|}{ Responden } \\
\hline & & $\begin{array}{l}\text { Frekuensi } \\
\text { (F) }\end{array}$ & $\begin{array}{l}\text { Persentase } \\
(\%)\end{array}$ \\
\hline Sangat Sesuai & $4.01-5.00$ & 4 & 4.0 \\
\hline Sesuai & $3.01-4.00$ & 54 & 54.0 \\
\hline Kurang Sesuai & $2.01-3.00$ & 36 & 36.0 \\
\hline Tidak Sesuai & $1.01-2.00$ & 6 & 6.0 \\
\hline Sangat Tidak Sesuai & $0.00-1.00$ & 0 & 0.0 \\
\hline \multicolumn{2}{|l|}{ Total } & 100 & 100.0 \\
\hline
\end{tabular}

Sumber: Data setelah diolah, 2014

Tabel 4.5 terlihat frekuensi dan persentase tanggapan responden mengenai bauran produk yang diterapkan dalam meningkatkan kepuasan nasabah kebanyakan memberikan jawaban sesuai yaitu sebanyak 54 orang atau $54.0 \%$. Sementara sebanyak 36 orang atau $36.0 \%$ kategori jawaban kurang sesuai, 6 orang atau $6.0 \%$ kategori jawaban tidak sesuai dan hanya 4 orang atau $4.0 \%$ kategori jawaban sangat sesuai. Ini berarti bahwa belum seluruhnya responden mendapatkan layanan produk yang ditawarkan, atau dengan kata lain produk asuransi yang ditawarkan tersebut belum sesuai keinginan nasabah.

\section{Harga (X2)}

Harga adalah nilai suatu produk yang diukur dengan uang dan yang telah ditetapkan oleh PT. Jasa Raharja Putera (Persero) Tbk. Makassar . Harga dalam hal ini berupa imbalan, diskon dan bonus. Berikut tanggapan responden mengenai bauran pemasaran harga ditunjukkan pada Tabel 4.6 dibawah ini: 
Tabel 4.6

Frekuensi dan Persentase mengenai Harga

\begin{tabular}{|c|c|c|c|}
\hline \multirow[b]{2}{*}{ Kategori } & \multirow{2}{*}{$\begin{array}{l}\text { Skala Interval } \\
\text { Likert }\end{array}$} & \multicolumn{2}{|c|}{ Responden } \\
\hline & & $\begin{array}{l}\text { Frekuensi } \\
\text { (F) }\end{array}$ & $\begin{array}{l}\text { Persentase } \\
(\%)\end{array}$ \\
\hline Sangat Sesuai & $4.01-5.00$ & 34 & 34.0 \\
\hline Sesuai & $3.01-4.00$ & 60 & 60.0 \\
\hline Kurang Sesuai & $2.01-3.00$ & 6 & 6.0 \\
\hline Tidak Sesuai & $1.01-2.00$ & 0 & 0.0 \\
\hline Sangat Tidak Sesuai & $0.00-1.00$ & 0 & 0.0 \\
\hline Total & & 100 & 100.0 \\
\hline
\end{tabular}

Sumber: Data setelah diolah, 2014

Tabel 4.6 terlihat frekuensi dan persentase tanggapan responden mengenai bauran harga yang diterapkan dalam meningkatkan kepuasan nasabah kebanyakan memberikan jawaban sesuai yaitu sebanyak 60 orang atau $60.0 \%$, menyatakan sangat sesuai ada 34 orang atau $34.0 \%$ dan kurang sesuai ada 6 orang atau $6.0 \%$. Mengenai bauran harga yang diterapkan perusahaan kebanyakan responden puas karena jawaban yang diberikan kebanyakan telah sesuai.

\section{Promosi (X3)}

Promosi adalah cara menyampaikan informasi produk yang dipergunakan PT. Jasa Raharja Putera (Persero) Tbk. Makassar. Promosi tersebut dilakukan langsung kepada nasabah. Berikut tanggapan responden mengenai bauran pemasaran promosi ditunjukkan pada Tabel 4.7 dibawah ini: 
Tabel 4.7

Frekuensi dan Persentase mengenai Promosi

\begin{tabular}{|c|c|c|c|}
\hline \multirow[b]{2}{*}{ Kategori } & \multirow{2}{*}{$\begin{array}{l}\text { Skala Interval } \\
\text { Likert }\end{array}$} & \multicolumn{2}{|c|}{ Responden } \\
\hline & & $\begin{array}{l}\text { Frekuensi } \\
\text { (F) }\end{array}$ & $\begin{array}{l}\text { Persentase } \\
(\%)\end{array}$ \\
\hline Sangat Sesuai & $4.01-5.00$ & 61 & 61.0 \\
\hline Sesuai & $3.01-4.00$ & 35 & 35.0 \\
\hline Kurang Sesuai & $2.01-3.00$ & 4 & 4.0 \\
\hline Tidak Sesuai & $1.01-2.00$ & 0 & 0.0 \\
\hline Sangat Tidak Sesuai & $0.00-1.00$ & 0 & 0.0 \\
\hline Total & & 100 & 100.0 \\
\hline
\end{tabular}

Sumber: Data setelah diolah, 2014

Tabel 4.7 terlihat frekuensi dan persentase tanggapan responden mengenai bauran promosi yang diterapkan dalam meningkatkan kepuasan nasabah kebanyakan memberikan jawaban sangat sesuai yaitu sebanyak 61 orang atau $61.0 \%$. Pernyataan jawaban sangat sesuai menunjukkan bahwa nasabah tertarik atas promosi yang diterapkan oleh pihak PT. Jasa Raharja Putera (Persero) Tbk. Makassar, dan hal tersebut akan memberikan pengaruh terhadap kepuasan nasabah pada PT. Jasa Raharja Putera (Persero) Tbk. Makassar .

\section{Lokasi (X4)}

Lokasi adalah daerah di mana PT. Jasa Raharja Putera (Persero) Tbk. Makassar didirikan. Lokasi dalam hal ini ditentukan oleh tempat yang strategis, mudah dijangkau dan memiliki cabang yang banyak. Berikut tanggapan responden mengenai bauran pemasaran lokasi ditunjukkan pada Tabel 4.8 dibawah ini: 
Tabel 4.8

Frekuensi dan Persentase mengenai Lokasi

\begin{tabular}{|c|c|c|c|}
\hline \multirow[b]{2}{*}{ Kategori } & \multirow{2}{*}{$\begin{array}{l}\text { Skala Interval } \\
\text { Likert }\end{array}$} & \multicolumn{2}{|c|}{ Responden } \\
\hline & & $\begin{array}{l}\text { Frekuensi } \\
\text { (F) }\end{array}$ & $\begin{array}{l}\text { Persentase } \\
(\%)\end{array}$ \\
\hline Sangat Sesuai & $4.01-5.00$ & 24 & 24.0 \\
\hline Sesuai & $3.01-4.00$ & 44 & 44.0 \\
\hline Kurang Sesuai & $2.01-3.00$ & 18 & 18.0 \\
\hline Tidak Sesuai & $1.01-2.00$ & 14 & 14.0 \\
\hline Sangat Tidak Sesuai & $0.00-1.00$ & 0 & 0.0 \\
\hline \multicolumn{2}{|l|}{ Total } & 100 & 100.0 \\
\hline
\end{tabular}

Sumber: Data setelah diolah, 2014

Tabel 4.8 terlihat frekuensi dan persentase tanggapan responden mengenai bauran lokasi yang diterapkan dalam meningkatkan kepuasan nasabah kebanyakan memberikan jawaban sesuai yaitu sebanyak 44 responden atau 44.0\%. Ini berarti bahwa kebanyakan responden telah puas atas lokasi yang sudah strategis, sehingga mudah dikenali dan dijangkau, sebagai suatu pertimbangan bagi nasabah untuk menabung di PT. Jasa Raharja Putera (Persero) Tbk. Makassar .

\section{Karyawan (X5)}

Karyawan adalah staf yang terlibat langsung dalam menjalankan segala aktivitas perusahaan. Karyawan dalam hal ini dinilai dari performa menarik yang ditunjukkan, ramah dalam melayani nasabah, profesional dan handal di bidang kerjanya. Berikut tanggapan responden mengenai karyawan ditunjukkan pada Tabel 4.9 dibawah ini: 
Tabel 4.9

Frekuensi dan Persentase mengenai Karyawan

\begin{tabular}{|c|c|c|c|}
\hline \multirow{2}{*}{ Kategori } & \multirow{2}{*}{$\begin{array}{l}\text { Skala Interval } \\
\text { Likert }\end{array}$} & \multicolumn{2}{|c|}{ Responden } \\
\hline & & $\begin{array}{l}\text { Frekuensi } \\
\text { (F) }\end{array}$ & $\begin{array}{l}\text { Persentase } \\
(\%)\end{array}$ \\
\hline Sangat Sesuai & $4.01-5.00$ & 52 & 52.0 \\
\hline Sesuai & $3.01-4.00$ & 45 & 45.0 \\
\hline Kurang Sesuai & $2.01-3.00$ & 3 & 3.0 \\
\hline Tidak Sesuai & $1.01-2.00$ & 0 & 0.0 \\
\hline Sangat Tidak Sesuai & $0.00-1.00$ & 0 & 0.0 \\
\hline Total & & 100 & 100.0 \\
\hline
\end{tabular}

Sumber: Data setelah diolah, 2014

Tabel 4.9 terlihat frekuensi dan persentase tanggapan responden mengenai karyawan yang diterapkan dalam meningkatkan kepuasan nasabah kebanyakan memberikan jawaban sangat sesuai yaitu sebanyak 52 responden atau 52.0\%. Dapat dijelaskan bahwa karyawan PT. Jasa Raharja Putera (Persero) Tbk. Makassar sudah memenuhi kriteria karyawan yang handal dan profesional dalam memberikan pelayanan kepada nasabahnya, dengan demikian berpengaruh terhadap kepuasan nasabah.

\section{Bukti Fisik (X6)}

Bukti Fisik adalah kondisi fisik yang nyata yang dapat digunakan untuk menunjang aktivitas pelayanan asuransi. Bukti fisik tersebut berupa ketersediaan gedung, karyawan yang siap sedia, alat dan perlengkapan kerja yang lengkap, kantor dan armada. Berikut tanggapan responden mengenai bauran pemasaran sarana fisik ditunjukkan pada Tabel 4.10 dibawah ini: 
Tabel 4.10

Frekuensi dan Persentase mengenai Bukti Fisik

\begin{tabular}{|c|c|c|c|}
\hline \multirow[b]{2}{*}{ Kategori } & \multirow{2}{*}{$\begin{array}{l}\text { Skala Interval } \\
\text { Likert }\end{array}$} & \multicolumn{2}{|c|}{ Responden } \\
\hline & & $\begin{array}{l}\text { Frekuensi } \\
\text { (F) }\end{array}$ & $\begin{array}{l}\text { Persentase } \\
(\%)\end{array}$ \\
\hline Sangat Sesuai & $4.01-5.00$ & 12 & 12.0 \\
\hline Sesuai & $3.01-4.00$ & 62 & 62.0 \\
\hline Kurang Sesuai & $2.01-3.00$ & 21 & 21.0 \\
\hline Tidak Sesuai & $1.01-2.00$ & 5 & 5.0 \\
\hline Sangat Tidak Sesuai & $0.00-1.00$ & 0 & 0.0 \\
\hline Total & & 100 & 100.0 \\
\hline
\end{tabular}

Sumber: Data setelah diolah, 2014

Tabel 4.10 terlihat frekuensi dan persentase tanggapan responden mengenai bauran bukti fisik yang diterapkan dalam meningkatkan kepuasan nasabah kebanyakan memberikan jawaban sesuai yaitu sebanyak 62 orang atau $62.0 \%$. Artinya, PT. Jasa Raharja Putera (Persero) Tbk. Makassar telah dapat memenuhi kebutuhan akan pelayanan yang diinginkan oleh nasabah. Selain itu, prosedur pelayanan memudahkan nasabah mendapatkan layanan asuransi.

\section{Proses (X7)}

Proses adalah gabungan semua aktivitas yang mencakup prosedur, jadwal pekerjaan, mekanisme, aktivitas dan hal-hal rutin di mana jasa di hasilkan dan disampaikan kepada nasabah. Proses dalam hal ini dimulai dari pengambilan nomor antrian, pembukaan rekening, akses data dan sistem online. Berikut tanggapan responden mengenai bauran proses ditunjukkan pada Tabel 4.11 dibawah ini: 
Tabel 4.11

Frekuensi dan Persentase mengenai Proses

\begin{tabular}{|l|c|c|c|}
\hline Kategori & $\begin{array}{l}\text { Skala Interval } \\
\text { Likert }\end{array}$ & $\begin{array}{l}\text { Responden } \\
\text { Frekuensi } \\
(\text { F) }\end{array}$ & $\begin{array}{l}\text { Persentase } \\
(\%)\end{array}$ \\
\hline Sangat Sesuai & $4.01-5.00$ & 74 & 74.0 \\
Sesuai & $3.01-4.00$ & 23 & 23.0 \\
Kurang Sesuai & $2.01-3.00$ & 3 & 3.0 \\
Tidak Sesuai & $1.01-2.00$ & 0 & 0.0 \\
Sangat Tidak Sesuai & $0.00-1.00$ & 0 & 0.0 \\
\hline \multicolumn{2}{|c|}{ Total } & 100 & 100.0 \\
\hline
\end{tabular}

Sumber: Data setelah diolah, 2014

Tabel 4.11 terlihat frekuensi dan persentase tanggapan responden mengenai bauran proses yang diterapkan dalam meningkatkan kepuasan nasabah kebanyakan memberikan jawaban sangat sesuai yaitu sebanyak 74 responden atau $74.0 \%$. Artinya bahwa proses yang diterapkan pada PT. Jasa Raharja Putera (Persero) Tbk. Makassar sudah menunjukkan kemudahan bagi nasabah karena telah menerapkan proses pengambilan nomor antrian yang tidak terlalu lama karena telah menggunakan teknologi modern, pelayanan pembukaan rekening oleh staf yang handal dan profesional dan akses data yang cepat.

\section{Analisis Faktor Bauran Pemasaran terhadap Kepuasan Nasabah}

Analisis hasil penelitian mengenai faktor bauran pemasaran terhadap kepuasan nasabah pada PT. Jasa Raharja Putera (Persero) Tbk. Makassar dianalisis dengan menggunakan metode kualitatif dan kuantitatif. Analisis kuantitatif digunakan untuk membuktikan hipotesis yang diajukan dengan menggunakan model analisis regresi linier berganda, sedangkan analisis kualitatif digunakan untuk menelaah pembuktian analisis kuantitatif. 
Pembuktian ini dimaksudkan untuk menguji variasi dari model regresi yang digunakan dalam menerangkan variabel bebas $(X)$ terhadap variabel terikat $(Y)$ dengan cara menguji kemaknaan dari koefisien regresinya.

Berikut rangkuman hasil olah data yang menyajikan nilai $R$ dan $R^{2}$, melihat tingkat signifikansi secara simultan dan parsial serta variabel dominan sebagaimana ditunjukkan pada Tabel 4.12 di bawah ini:

Tabel 4.12

Rangkuman Hasil Perhitungan Regresi

\begin{tabular}{|c|c|c|c|c|c|}
\hline \multirow{3}{*}{\begin{tabular}{|l|} 
Simultan \\
Koefisien Korelasi \\
$R=0.854$ \\
\end{tabular}} & & Darsial & & & \multirow{3}{*}{$\begin{array}{l}\text { Koefisien } \\
\text { Regresi }\end{array}$} \\
\hline & \multicolumn{4}{|c|}{ Koefisien Determinan } & \\
\hline & \multicolumn{4}{|c|}{$R^{2}=0.729$} & \\
\hline F-hitung & Variabel & t-hitung & t-tabel & Sig. & B \\
\hline 15.308 & $\mathrm{X} 1$ & 2.703 & 1.7613 & 0.035 & 0.617 \\
\hline Sig. $=0.000$ & $\mathrm{X} 2$ & 2.354 & 1.7613 & 0.043 & 0.594 \\
\hline \multirow[t]{5}{*}{$P<0.05$} & X3 & 1.980 & 1.7613 & 0.048 & 0.523 \\
\hline & $\mathrm{X} 4$ & 3.264 & 1.7613 & 0.030 & 0.637 \\
\hline & $\times 5$ & 3.716 & 1.7613 & 0.029 & 0.691 \\
\hline & $\mathrm{X} 6$ & 4.258 & 1.7613 & 0.013 & 0.705 \\
\hline & $\mathrm{X} 7$ & 4.454 & 1.7613 & 0.000 & 0.715 \\
\hline
\end{tabular}

Sumber: Data dari Lampiran Regresi, 2014

Berdasarkan perhitungan dengan bantuan program SPSS diperoleh persamaan regresi liner berganda adalah sebagai berikut:

$Y=3.775+0.617 X_{1}+0.594 X_{2}+0.523 X_{3}+0.637 X_{4}+0.691 X_{5}+0.705 X_{6}+0.715 X_{7}$

Persamaan regresi di atas terdapat nilai $\beta_{0}$ atau nilai konstanta sebesar 3.775 . Hal ini menunjukkan bahwa jika variabel independent seluruhnya dianggap bernilai 0 , maka kepuasan nasabah (Y) adalah sebesar 3.775. Indikasi dari pengaruh variabel lain yang tidak diteliti dalam analisis faktor bauran pemasaran terhadap kepuasan nasabah pada PT. Jasa Raharja Putera (Persero) Tbk. Makassar . Selain itu persamaan regresi linier 
berganda di atas, terdapat nilai koefisien regresi variabel bebas $\mathrm{X}$ adalah positif. Nilai koefisien $X$ yang positif artinya apabila terjadi perubahan pada variabel $X$, akan menyebabkan perubahan secara searah pada variabel $\mathrm{Y}$.

Koefisien Regresi X1 (produk) sebesar 0.617 yang berarti bahwa jika X1 (produk) naik sebesar satu satuan, akan memberikan pengaruh terhadap kepuasan nasabah sebesar 0.617 satuan, dengan asumsi bahwa variabel lain dianggap konstan.

Koefisien Regresi X2 (harga) sebesar 0.594 yang berarti bahwa jika X2 (harga) naik sebesar satu satuan, akan memberikan pengaruh terhadap kepuasan nasabah sebesar 0.594 satuan, dengan asumsi bahwa variabel lain dianggap konstan.

Koefisien Regresi X3 (promosi) sebesar 0.523 yang berarti bahwa jika X3 (promosi) naik sebesar satu satuan, akan memberikan pengaruh terhadap kepuasan nasabah sebesar 0.523 satuan, dengan asumsi bahwa variabel lain dianggap konstan. Koefisien Regresi X4 (lokasi) sebesar 0.637 yang berarti bahwa jika X4 (lokasi) naik sebesar satu satuan, akan memberikan pengaruh terhadap kepuasan nasabah sebesar 0.637 satuan, dengan asumsi bahwa variabel lain dianggap konstan.

Koefisien Regresi X5 (karyawan) sebesar 0.691 yang berarti bahwa jika X5 (karyawan) naik sebesar satu satuan, akan memberikan pengaruh terhadap kepuasan nasabah sebesar 0.691 satuan, dengan asumsi bahwa variabel lain dianggap konstan. Koefisien Regresi X6 (bukti fisik) sebesar 0.705 yang berarti bahwa jika X6 (bukti fisik) naik sebesar satu satuan, akan memberikan pengaruh terhadap kepuasan nasabah sebesar 0.705 satuan, dengan asumsi bahwa variabel lain dianggap konstan. 
Koefisien Regresi X7 (proses) sebesar 0.715 yang berarti bahwa jika X7 (proses) naik sebesar satu satuan, akan memberikan pengaruh terhadap kepuasan nasabah sebesar 0.715 satuan, dengan asumsi bahwa variabel lain dianggap konstan.

Selanjutnya hasil perhitungan regresi untuk nilai $R$ (koefisien korelasi) untuk melihat pengaruh simultan dan nilai $R^{2}$ (koefisien determinan) untuk melihat pengaruh parsial variabel-variabel yang diteliti. Diketahui bahwa nilai koefisien korelasi $(R)=0.854$ berarti bahwa variabel independen bauran pemasaran yang terdiri dari produk, harga, promosi, lokasi, karyawan, bukti fisik dan proses menunjukkan pengaruh simultan terhadap variabel dependen kepuasan nasabah, setelah dipersentasekan diperoleh hasil sebesar $85.4 \%$.

Besarnya pengaruh (kontribusi) variabel bebas (X) secara bersama- sama terhadap variabel tidak bebas $(\mathrm{Y})$ dapat dilihat dari besarnya koefisien determinan ganda $\left(R^{2}\right)$. Nilai koefisien determinasi adalah diantara nol dan satu. Jika $R^{2}$ yang diperoleh dari hasil perhitungan adalah 0.729 , maka dapat dikatakan pengaruh masing-masing variabel bebas terhadap variabel terikat adalah besar. Hasil pengujian hipotesis penelitian menunjukkan bahwa variabel bebas yang diteliti berpengaruh positif dan signifikan dengan nilai kontribusi $\mathrm{R}^{2}$ sebesar $72.9 \%$, menjelaskan bahwa produk, harga, promosi, lokasi, karyawan, bukti fisik dan proses menentukan peningkatan kepuasan nasabah. Sedangkan pengaruh variabel lain yang tidak diteliti hanya $27.1 \%$.

Hasil uji statistik F atau uji signifikansi simultan, pada dasarnya menunjukkan apakah semua variabel bebas yang dimasukkan dalam model mempunyai pengaruh secara bersama-sama terhadap variabel dependen $\mathrm{Y}$. Uji $\mathrm{F}$ ini dilakukan dengan

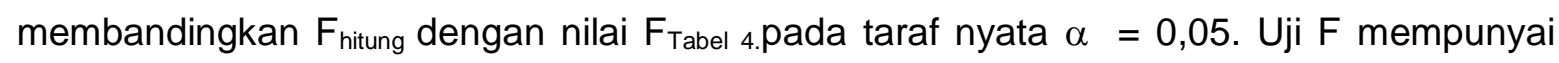
pengaruh signifikan apabila $F_{\text {hitung }}$ lebih besar dari $F_{\text {Tabel 4.atau probabilitas kesalahan }}$ kurang dari $5 \%(P<0,05)$. 


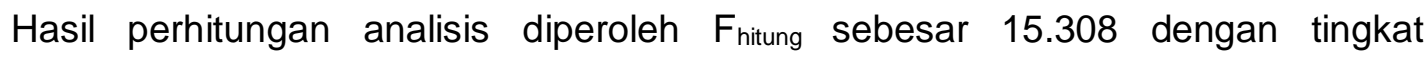
probabilitas 0.000 (signifikan) dan probabilitas jauh lebih kecil dari 0.05 , berarti bahwa hipotesis pertama penelitian ini diterima kebenarannya.

Uji t untuk menguji kemaknaan atau keberartian koefisien regresi partial. Pengujian melalui uji $\mathrm{t}$ pada taraf nyata $\alpha=0.05$. Uji $\mathrm{t}$ berpengaruh signifikan apabila hasil perhitungan thitung probabilitas kesalahan lebih kecil dari $5 \%(p<0.05)$. Berdasarkan Tabel 4.18 hasil uji-t di atas diketahui bahwa t-hitung untuk seluruh variabel bebas menunjukkan tingkat signifikansi $\mathrm{P}<0.05$ yang berarti memberikan pengaruh positif dan signifikan.

Setelah diketahui adanya pengaruh simultan dan parsial, maka untuk mengetahui variabel dominan penelitian ditunjukkan dari hasil perolehan nilai B (koefisien regresi). Memperhatikan besaran koefisien regresi (B), maka diketahui bahwa variable bebas bauran proses yang dominan berpengaruh terhadap kepuasan nasabah pada PT. Jasa Raharja Putera (Persero) Tbk. Makassar nilai B sebesar 0.715., berarti bahwa hipotesis kedua dari penelitian ini diterima kebenarannya.

\section{Pembahasan}

\section{Produk terhadap Kepuasan Nasabah}

PT. Jasa Raharja Putera (Persero) berupaya untuk terus meningkatkan jumlah nasabahnya dengan memperkenalkan berbagai jenis produk yang dapat dipergunakan atau dimiliki di dalam melakukan penabungan, penyimpanan aset (kekayaan) atau kegiatan-kegiatan yang memudahkan bagi nasabah untuk melakukan transaksi dalam menjamin dana-dananya untuk dikelolah oleh pihak jasa asuransi, sehingga nasabah menjadi puas dalam mendapatkan pelayanan produk yang diberikan oleh pihak asuransi. Jasa asuransi saat ini telah mengeluarkan produk layanan yang sesuai dengan jenis produk, ketersediaan produk yang akan ditawarkan dan 
kualitas produk asuransi yang diberikan kepada nasabah. Produk asuransi yang ditawarkan memiliki berbagai keunggulan yang dapat dirasakan oleh nasabah sesuai dengan pilihan dari produk yang diinginkan dalam memenuhi kepuasan nasabah.

\section{Harga terhadap Kepuasan Nasabah}

PT. Jasa Raharja Putera (Persero) dalam menerapkan bauran harga di dalam menghidupkan aktivitas asuransi untuk memberikan pelayanan yang terbaik dalam memuaskan nasabah atas pelayanan yang diterapkan. Penetapan harga yang diterapkan dalam memenuhi kepuasan nasabah yaitu memberikan imbalan sebagai keuntungan yang diperoleh nasabah. Selain itu juga menerapkan diskon yang dilakukan antara pihak pemberi asuransi kepada nasabah. Selain itu pihak asuransi juga memberikan keuntungan kepada nasabah atas setiap produk yang ditawarkan.

Selain itu dalam penetapan harga berupa biaya administrasi, biaya transaksi dan suku bunga pada dasarnya merupakan kegiatan bauran harga yang diterapkan oleh Jasa Raharja Putera dalam memenuhi kepuasan pelayanan kepada nasabah. Kegiatan pengenaan biaya administrasi pada dasarnya pihak jasa asuransi menginginkan nasabah untuk memberikan nilai harga kepada pihak jasa asuransi atas jasa pengelolaan dana yang dipercayakan kepadanya, sehingga biaya administrasi merupakan bentuk atau wujud dari nilai balas jasa atas kegiatan secara administratif yang merupakan bagian dari kegiatan pembiayaan yang memiliki harga yang dinyatakan dalam pembiayaan administrasi dimaksudkan untuk menjamin kegiatan pelayanan yang dilakukan oleh pihak jasa asuransi dalam memberikan kepuasan kepada nasabah.

\section{Promosi terhadap Kepuasan Nasabah}

PT. Jasa Raharja Putera (Persero) di dalam mengembangkan kegiatan usahanya, khususnya yang berkaitan dengan usaha asuransi baik asuransi 
jiwa, asuransi kecelakaan, kebakaran ataupun lainnya, senantiasa mempromosikan produk-produk yang dimilikinya termasuk promosi berbagai keunggulan dan kelebihan dari produk yang ditawarkan, dalam rangka menarik jumlah nasabah untuk menabung dan memberikan berbagai keuntungan atas kegiatan pelayanan yang dilakukan oleh pihak jasa asuransi. Bentuk promosi yang dilakukan berupa sales promotion, personal selling, publisitas dan periklanan.

Untuk sales promotion biasanya pihak jasa asuransi dalam hal ini menawarkan produk kepada nasabah untuk melakukan pengenalan jenis- jenis produk sesuai dengan keunggulan dan kelebihan dari produk tersebut, serta mempromosikan kepada setiap nasabah kemudahan yang diperoleh selama menjadi nasabah asuransi sesuai tingkat kebutuhan nasabah di dalam memenuhi kepuasannya. Dalam mempromosikan produk juga melakukan penawaran kepada nasabah yang dilakukan oleh karyawan. Biasanya karyawan menawarkan produk unggulan kepada nasabah dengan memberikan informasi berbagai petunjuk dan prosedur dalam pengurusannya yang mudah dan cepat.

Pihak Jasa asuransi dalam melakukan promosi kepada nasabah juga melakukan kegiatan promosi publisitas. Kegiatan promosi publisitas dilakukan melalui pendekatan promosi mouth to mouth atau dari mulut ke mulut yaitu dari mulut karyawan berupa informasi ke nasabah atau dari mulut nasabah melalui informasi di papan billboard atau berbagai informasi yang diperoleh sampai ke nasabah lainnya.

\section{Lokasi terhadap Kepuasan Nasabah}

PT. Jasa Raharja Putera (Persero) merupakan salah satu perusahaan asuransi yang terletak di tempat yang strategis yaitu berada di tengah- tengah Kota Makassar yang mudah dijangkau oleh masyarakat yang ingin 
menjadi nasabah. Kemudahan terjangkau tersebut sangat ditentukan oleh lokasi yang memiliki tempat yang strategis, mudah dijangkau oleh berbagai kendaraan serta memiliki akses dari banyak cabang yang ada di Indonesia dan lainnya. Hal ini yang mendukung nasabah menjadikan lokasi sebagai pertimbangan yang mempengaruhi kepuasan nasabah.

PT. Jasa Raharja Putera (Persero) berada di jalan yang mudah didatangi, dilewati oleh beberapa jalur kendaraan yang dapat menghubungkan dari beberapa jalur lainnya, bangunan yang megah dilengkapi dengan berbagai fasilitas yang mendukung tepat tersebut strategis. Pertimbangan letak strategis ini dengan fasilitas bangunan yang dilengkapi dengan otomasi kantor menjadi suatu alasan bagi nasabah untuk menjadi nasabah di PT. Jasa Raharja Putera (Persero) dalam rangka memenuhi kebutuhan dan keinginannya untuk memuaskan nasabah.

Uraian tersebut di atas menjadi penting untuk disikapi oleh pihak asuransi atas pemenuhan kepuasan kepada nasabah dalam rangka menciptakan suasana yang kondusif dalam membangun kemitraan antara pihak PT. Jasa Raharja Putera (Persero) dengan nasabah sebagai wujud dari penerapan bauran strategi pemasaran lokasi/tempat yang dapat dijangkau langsung oleh nasabah.

\section{Karyawan terhadap Kepuasan Nasabah}

Dalam memenuhi kepuasan nasabah, PT. Jasa Raharja Putera berupaya untuk menyiapkan kualitas sumber daya manusia (karyawan) yang memiliki kemampuan dalam memenuhi kepuasan nasabah atas pelayanan yang diberikan. Untuk itu karyawan dianjurkan untuk memiliki performa kerja yang menarik, keramahan dalam melayani nasabah, profesional dan handal di bidang kerjanya. 
Mengingat pentingnya pemenuhan kepuasan nasabah, maka pihak jasa asuransi juga telah mempersiapkan karyawan yang profesional dalam bidang pelayanan dan mengembangkan informasi yang terkontribusikan dengan baik, khususnya yang berkaitan dengan pelayanan langsung yang dilakukan oleh para teller, bagian perkreditan, bagian pengembangan SDM dan bagian-bagian unit lain yang menjadi satu kesatuan untuk memberikan dan menunjukkan kepada nasabah bahwa karyawan tersebut merupakan karyawan yang memiliki profesionalisme dalam memberikan pelayanan untuk memberikan kepuasan kepada nasabah. Wujud dari kemampuan dalam memberikan pelayanan untuk kepuasan nasabah, maka karyawan harus mampu mengembangkan aksesibilitas kerja yang handal. Kehandalan dari karyawan ditunjukkan dengan kemandirian memberikan pelayanan, percaya diri dalam melayani dan menunjukkan tingkat keahlian dan kemahiran memberikan layanan terbaik dengan cepat, mudah, lancar dan sesuai prosedur untuk memenuhi kepuasan nasabah.

Uraian-uraian di atas merupakan hal yang menjadi pertimbangan untuk terus ditingkatkan dalam memenuhi kepuasan nasabah dengan menciptakan karyawan yang memiliki performa menarik yang ditunjukkan, ramah dalam melayani nasabah, profesional dan handal di bidang kerjanya, untuk memenuhi kepuasan nasabah dalam melakukan transaksi asuransi.

\section{Bukti Fisik terhadap Kepuasan Nasabah}

PT. Jasa Raharja Putera (Persero) merupakan salah satu aset asuransi yang mengelola dana masyarakat dan menyalurkan dana tersebut untuk menunjang kegiatan pembangunan nasional, sehingga keberadaannya merupakan bukti fisik yang membuktikan sebagai aset pembangunan, seperti tersedianya gedung, karyawan yang siap sedia, alat dan 
perlengkapan kerja dan sistem kerja yang cepat. Hal ini merupakan bukti fisik yang nyata dimiliki oleh pihak jasa asuransi dalam memberikan kepuasan kepada nasabah. PT. Jasa Raharja Putera (Persero) mempunyai gedung yang mewah dilengkapi dengan berbagai informasi yang mendukung gedung tersebut sebagai perusahaan yang memiliki aset di dalam mengembangkan aktivitas kerja. Mengembangkan suatu bukti fisik aktivitas pelayanan tidak hanya ditunjang oleh gedung yang mewah, tetapi dituntut adanya karyawan yang siap sedia untuk memberikan aktivitas pelayanan kepada nasabah agar kontinuitas aktivitas asuransi berjalan dengan lancar, karena didukung oleh adanya SDM berupa karyawan yang siap memberikan layanan terbaik karena keberadaannya menjadikan kepuasan nasabah dapatterpenuhi.

Untuk memenuhi kepuasan nasabah, bukti fisik berupa perlengkapan kerja yang lengkap menjadi suatu alat dalam mempermudah melakukan aktivitas asuransi. Alat dan perlengkapan kerja tersebut termasuk ketersediaan tempat duduk, counter pelayanan, mesin komputer, faks, telepon, AC, papan informasi, dan berbagai perlengkapan lainnya yang dimiliki diperuntukkan untuk memenuhi kepuasan nasabah.

PT. Jasa Raharja Putera (Persero) menyadari pula bahwa untuk memberikan kepuasan kepada nasabah, maka diperlukan adanya suatu sistem kerja yang cepat, sebagai bukti fisik yang harus ditunjukkan oleh pihak jasa asuransi. Untuk memenuhi hal tersebut, maka sistem kerja yang diterapkan yaitu menggunakan sistem kerja informasi manajemen yang berbasis teknologi seperti sistem online 24 jam dan menggunakan sistem LAN (local area network) untuk mempermudah aksesibilitas data-data, informasi dan penawaran produk asuransi. Hal ii dimaksudkan untuk memenuhi kepuasan nasabah. 


\section{Proses terhadap Kepuasan Nasabah}

PT. Jasa Raharja Putera (Persero) dalam mengembangkan strategi bauran pemasaran berupa proses, senantiasa dilakukan sebagai wujud dari prosedur kerja yang diterapkan dalam melakukan berbagai aktivitas pelayanan kepada nasabah. Proses merupakan salah satu hal yang berperan penting dalam memenuhi kepuasan nasabah. Wujud proses tersebut berupa proses prasyarat yang tidak berbelit-belit, sesuai standar, prosedur dan sistem yang berlaku.

Terlihat di BNI bahwa untuk mengembangkan aktivitas pelayanan strategi bauran pemasaran proses prasyarat menjadi nasabah asuransi prosedur untuk menghindari adanya pelayanan yang berbelit-belit. Hal ini dimaksudkan untuk memenuhi kepuasan nasabah agar tidak merasa bosan atau lama menunggu serta menertibkan kegiatan pelayanan berdasarkan urutan nasabah yang dapat untuk mendapatkan pelayanan. Akses data nasabah merupakan bagian dari kegiatan proses pelayanan yang harus ditindaklanjuti. Dengan adanya proses data melalui input-input data dan informasi, maka pihak jasa asuransi akan memberikan output kepada nasabah sesuai dengan proses kegiatan pelayanan yang diinginkan. Makin cepat data dimasukkan, maka makin cepat pula data dimasukkan oleh karyawan dan hal ini memudahkan nasabah untuk menghasilkan output hasil pelayanan yang mudah dan cepat dalam memenuhi kepuasan nasabah.

\section{Kesimpulan}

Berdasarkan hasil dan pembahasan di atas, maka disimpulkan sebagai berikut: 
1. Bauran pemasaran yang terdiri dari produk, harga, promosi, lokasi, karyawan, bukti fisik dan proses berpengaruh secara simultan positif dan signifikan terhadap kepuasan nasabah pada PT. Jasa Raharja Putera (Persero) Tbk. Makassar, yang ditunjukkan dari hasil perolehan nilai koefisien korelasi $(R)$, koefisien determinan $\left(R^{2}\right)$ dengan uji-F yang menunjukkan probabilitas $p<0.05$.

2. Bauran proses yang dominan berpengaruh terhadap kepuasan nasabah pada PT. Jasa Raharja Putera (Persero) Tbk. Makassar, berdasarkan hasil perolehan nilai koefisien regresi $(B)$ yang menunjukkan nilai yang positif yang tinggi dan probabilitas $p$ $<0.05$. Proses merupakan aktivitas asuransi yang diterapkan untuk memberikan layanan kepada nasabah yang memberikan pengaruh terhadap kepuasan nasabah PT. Jasa Raharja Putera (Persero) Tbk. Makassar. 


\section{DAFTAR PUSTAKA}

Anantha Raj A. Arokiaamy, 2012. The Effect of Marketing Mix and Customer Perception. http://www.journalofmarketing.co.id.

Assauri, Sofyan, 2011. Manajemen Pemasaran Produksi dan Operasi. Jakarta: Lembaga Penerbit Fakultas Ekonomi UI.

Barata, Atep. D., 2001. Pelayanan Prima. Elex Media Komputindo, Jakarta.

Boinate, Della J., 2008. Consumer Behavior. Third Edition. McGraw Hill Book Company, New York.

Cahyono, Sidar, 1999. Manajemen Pemasaran Jasa. Penerbit Dian Sarana Ilmu, Bandung.

Challender, Leon. G., 2009. Consumer Behavior. Fifth Edition. Prentice Hall, Inc., New Jersey.

Chun, Lin and Yin, Cheng, 2005. Marketing Action. Fifth Edition, South Western College Publishing, Ohio.

Doublert, Bilson, 2008. Panduan Riset Perilaku Konsumen. Penerbit Gramedia Pustaka, Jakarta.

DeRoss, Dick, 2006. Marketing Mix: Toward An Integrated Conceptual Framework. Journal of The Academy Marketing Science, Vol. 22, p. 99-113.

Dunga, John, 2007. Good Research Good Design in Research. Published by John Wiley and Sons., New York.

Emory dan Cooper, 1991. Sample Technique in Quantitative Research. John Wiley and Sons, New York.

Engel, James, F. R., 2004. Consumer Behavior. Eight Edition. The Dryden Press, Orlando.

Gaspersz, Vincent, 2003. Manajemen Bisnis Total - Total Quality Management. Jakarta: Penerbit PT. Gramedia Pustaka Utama.

George, TH, 2007. Marketing Mix: Product, Price, Distribution and Promotion.

Prentice Hall Jersey University Press, America.

Gouzali, Charles L . 2006. The History, Evaluation dan Principles Of Services Marketing: Poised For The New Millennium. Marketing Intelligence \& Planning 17/7, pp. 324336. 
Henderickson, James, 2009. Marketing and Satisfaction. Eight Edition. The Dryden Press, Orlando.

Holmes, Marthin, 2009. Marketing Mix: Product, Price, Distribution and Promotion.

Prentice Hall Jersey University Press, America.

Jispher, William, 2001. Marketing and Strategy in Marketing. McMIllan, Canada.

Kartasasmita, 2000. Pemasaran Produk dan Jasa. Penerbit Pustakajaya, Jakarta. Kerlinger,

Fred N. 2000. Asas-Asas Penelitian Behavioral. Yogyakarta: Gadjah

Mada University Press.

Kotler, Philip, 2008. Manajemen Pemasaran, Analisis Perencanaan, Implementasi dan Kontrol. Edisi 9 PT. Prenhallindo, Jakarta.

Lee, G., 2007. Principles of Marketing. $10^{\text {th }}$ ed. Published of Prentice Hall, New Jersey.

Lorenzo, Peter, 2009. Managing of Customer Behavior. Published by McGraw Hill Book Company, New York.

Matti Jaakkola, Kristian Moller, dkk, 2010. Strategic Marketing and Business Performance: $A$ Study in Three European Engineering Countries. http://www.journalofmarketing.co.id.

Mohammad Amzad HS, 2012. Investigating the Impact of Marketing Mix Elements on Tourist Satisfaction. http://www.journalofmarketing.co.id.

Muller, Hawkins, 2008. Customer Behavior in Research of Marketing. Prentice Hall Inc., New Jersey.

Munsray, Jacky, 2008. Pemasaran Jasa, Manusia, Teknologi dan Strategi. Penerbit Erlangga, Jakarta.

Nelson, Sharpe, 2000. The Stratified of Consumer In The Service Marketing. $10^{\text {th }}$ Edition, Prentice Hall, Ohio University Press 
